connect the psychics of the laboratory with those of real life".

The idea of using sensory thresholds to measure general ability or intelligence he took from Galton. In the United States, one of Galton's own pupils, J. McKeen Cattell, had applied laboratory tests to students, and, on assessing the results by Galton's method of correlation, had been surprised to find that the agreement of the various modes of assessment was extremely low. Cattell, Thorndike and others were consequently led to the conclusion that there was no general faculty of intelligence, as Galton had assumed, and that the mind was a "host of particular abilities". This negative result Spearman believed to be erroneous. Adapting a more elaborate statistical procedure from Karl Pearson and Yule, he endeavoured to eliminate the irrelevant factors which appeared to be obscuring the underlying correlations, and then found an almost perfect agreement between the various tests and assessments. These results he published in one of his earliest and most important articles in 1904- "On General Intelligence Objectively Determined and Measured". In this research he believed he had demonstrated "the profoundly important conclusion that there exists something which we may provisionally term general sensory discrimination"; and this he identified with "general ability" in Galton's sense. Few papers in psychology have given rise to such productive controversies and to so long a list of suggestive investigations.

In 1907 Spearman returned to England. At that time McDougall was interested in Galton's scheme for an anthropometric survey which should include intelligence tests. In France, Binet had produced his scale of tests ; and at University College, London, Karl Pearson had already been working with correlational methods applied to teachers' assessments of their pupils' mental characteristics. On McDougall's recommendation, Spearman was appointed reader in experimental psychology at the same College, and four years later became Grote professor of mind and logic. During the next twenty years, he and his research students were systematically engaged on demonstrating the supreme importance of a general intellectual factor, which he himself preferred to call, not intelligence, but $g$.

At first Spearman relied mainly on sensory tests of a laboratory type-the æsthesiometer, Galton's cartridge weights, and a dichord of his own invention for testing discrimination of pitch. Other workers in Great Britain, however, showed that better results might be secured by using tests of more complex abilities, particularly those involving the perception or use of logical relations, such as could be given without apparatus to large groups of children in school. These suggestions Spearman readily incorporated. His main interest, however, lay rather in the theoretical study of the mind in goneral than in educational or other practical applications.

His later work with tests of this new type led him to formulate his "fundamental noegenetic principles". According to this doctrine all intellectual processes were to be conceived as depending essentially upon the "education of relations and correlates". His first book, on "The Nature of Intelligence and the Principles of Cognition", gave a systematic picture of the workings of the human mind based on this hypothesis. It was quickly followed by a second volume on "The Abilities of Man", which gave the final statement of his 'two-factor theory'-the theory that all mental processes are pervaded by a single central function, combined with a second highly specific factor peculiar to each test or trait.

Later, in a smaller work on "The Creative Mind", Spearman endeavoured to show how his fundamental noegenetic laws could be applied to other intellectual fields. His last work, "Psychology Down the Ages", was a historical study in two volumes of the evolution of the chief doctrines of psychology, with the intention of showing how nearly all the more acceptable formulations were dim foreshadowings of his noegenotic laws.

In 1931, on his retirement, Spearman was made emeritus professor in the University of London. $\mathrm{He}$ had already been elected a fellow of the Royal Society, and been honourod by numerous scientific bodies in Germany, France, the United States and Czechoslovakia. All who worked with him, or discussed with him their common problems, will testify to his remarkable gift for inspiring enthusiasm both in his own colleagues and pupils and in those who were drawn to criticize his views. Few have possessed his powor of co-ordinating and concentrating the interests of numerous research workers on a single fertile scheme.

C. BURT.

\section{Dr. Frank Chapman}

The death has been announced of Dr. Frank Chapman, who for many years was head of the bird departments of the American Museum of Natural History, until his retirement in 1942.

Dr. Chapman was born at Englewood, New Jersey, on June 12, 1864, and on leaving school entered a New York bank. So keen on birds was young Chapman that he used to get up at daybreak, hunt birds on the way to the station, where he would arrive at 7.30, change into his city clothes and catch the 7.39 to town. All his spare time was devoted to collecting and studying birds, and after six years in the bank he decided that was not the life he could live. In 1886 he left the bank and two years later was appointed assistant to Dr. J. A. Allen, curator of mammals and birds in the American Museum of Natural History. This was the beginning of his long connexion with the Museum and the great bird collection which was so wonderfully developed under his charge. When Chapman joined the Museum the study collection consisted of only 300 skins! Under the joint care of Allen and Chapman the collection grew apace, and the latter made many expeditions to different parts of the States and the West Indies to secure further material.

Early in his career Chapman became interested in the life zones of the Andes, and thereafter most of his work was devoted to studying the birds of the Andes in Venezuela, Colombia, Chile and Peru. He published several monographs dealing with the subject and was the recognized authority on the birds of these regions. As Chapman himself wrote, he was more interested in watching live birds in the field than in collecting or studying skins, and after the First World War he settled on an ideal spot for the purpose. This was Barro Colorado Island in the Panama Canal zone, and there he built a house, called Fuertes House, after his friend the American bird artist. Here he could study and photograph wild life to his heart's content. Among the trees toucans, guans, parrots and woodhewers abounded, and down below were ocelots, peccaries and other interesting 
mammals. The joys of the place and what can be seen are described in "My Tropic Air Castle".

The love of birds brought Theodore Roosevelt and Chapman together, and through Roosevelt he was invited by Lord Grey to the British Embassy to talk birds. Later, during visits to Great Britain, he was taken by Lord Grey to see birds in the New Forest and along the banks of the Itchin, and a few years after he paid a visit to Fallodon which is vividly described in the "Autobiography of a Bird Lover".

Chapman was an ardent protectionist and for many years edited Bird Lore, the magazine of the Audubon Societies. In 1893 he published a useful "Handbook of Birds of Eastern North America", a revised edition of which appeared in 1912.

To Chapman the American Museum owes the development of the habitat groups for which that Museum is so famous.

In 1898 Chapman married Miss Embury, and the marriage was an ideally happy one, his wife developing as keen an interest in birds as her husband and often accompanying him in the field. N. B. KrnNeAR.

\section{Dr. H. E. Durham}

By the death at Cambridge, on October 5, of Dr. Herbert Edward Durham both bacteriology and botany lose a distinguished discoverer. Durham was born in London in 1866. He was the son of A. E. Durham, senior surgeon to Guy's Hospital and a grandson of William Ellis, the economist. Educated at University College School and King's College, Cambridge, Durham took first class honours in Parts I and II of the Natural Sciences Tripos at Cambridge in 1890, his medical qualification in 1892 and his F.R.C.S. in 1894. In 1894 he was appointed to a Gull Research Studentship and went to Vienna to work in Gruber's hygiene laboratory. There he and Gruber first directed attention in January 1896 to the diagnostic value of the agglutination of pathogenic organisms by the sera of animals immunized against them. Later in 1896 this test was applied by Widal for the diagnosis of typhoid fever. The reaction was known for a time as the Gruber-Durham reaction and later as the Widal reaction.

In 1896 Durham was appointed a member of a Royal Society committee upon diseases transmitted by tsetse flies. In 1897, while holding a Grocers' Scholarship and working at Cambridge, Durham described the Durham tube, a small inverted testtube placed in bacteriological media for the collection of the gas produced by fermentative organisms. In 1900 he headed the expedition sent by the Liverpool School of Tropical Medicine to Brazil to study yellow fever. Durham contracted the disease, but lived to lead, during 1901-3, the expedition sent by the London School of Tropical Medicine to Christmas Island and Malaya for the study of beriberi. From Malaya, Durham brought home samples of Derris elliptica and appears to have been the first to recognize the insecticidal properties of this plant.

In 1905 Durham was appointed supervisor of the laboratories of Messrs. H. P. Bulmor and Co., of Hereford, where he worked for thirty years upon problems of fermentation and apple culture in relation to cider production. In 1909 he took his Sc.D., Cambridge, and in 1935 retired to Cambridge, where he cultivated, in his garden there, many culinary plants and herbs which are rare in Great Britain. Many of these he had himself introduced, and several
Cambridge gardens still chorish those which ho gavo to their owners.

A retiring man who could be a charming and humorous companion, Durham acquired a wide culture and was always ready to give of his rich store of experience to his many correspondents and friends. He sent many valuable contributions to the "Dictionary of Gastronomy". Responsible for much original work, and also for much stimulation of others, he scattered his knowledge in private communications and did not always obtain full credit for his discoveries. Not least among his later activities were his hobbies of photography and lathe-work. While his bacteriological work is well known, his contributions to botany, and especially perhaps to apple culture and problems of fermentation, merit wider recognition. The sympathy of everyone will go out to Mrs. Durham, who survives him, and to his brother, Colonel F. R. Durham, secretary of the Royal Horticultural Society.

G. LAPAGE.

\section{Prof. C. E. Wright}

THe death of Prof. C. E. Wright, professor of gunnery and mathematics at the Military College of Science, Woolwich, occurred on October 30, 1945.

Charles Edward Wright was born on January 31, 1886. He studied mathematics at King's College, London, between 1903 and 1906, where he was awarded the Clothworkers' and Sambrooke Exhibitions and a Drew Gold Medal. After graduating he was appointed tutor at University Correspondence Gollege, Cambridge. During the War of 1914-18 he served with the Royal Engineers and was, for a short time, at the Research Department, Woolwich. $\mathrm{He}$ obtained the degree of M.Sc. by examination at Queen Mary College, London, in 1921.

In 1919, Wright took up the appointment of senior lecturer at the Military College of Science, Woolwich, where he spent the greater part of his career and where he was appointed professor shortly after the retirement of Prof. H. C. Plummer in 1940. Wright was wholeheartedly devoted to the instruction of army officers to fit them for technical staff appointments. The many students who have worked under him have proved their value during the recent War, where their services have proved indispensable in the development and production of weapons to meet the needs of the soldier in the field. Apart from his professional duties, Wright was actively engaged in voluntary war work, but alas, his zeal was greater than his strength.

He was an able mathematician and, in addition to his instructional duties and the preparation of Service text-books on ballistics, he found time to write several papers and notes published in the Philosophical Magazine and educational journals. The elegance exhibited in some of his mathematical work is most attractive. He was of a cheerful disposition and was popular with students and staff alike.

C. J. Tranter.

WE regret to announce the following deaths :

Dr. E. F. Armstrong, F.R.S., on December 14, aged sixty-seven.

Mr. A. Lucas, O.B.E., sometime chemist to the Egyptian Department of Antiquities, on December 9, aged seventy-six.

Mr. F. Milsom, for many years the official referee for Hepatics for the British Bryological Society, on December 5 . 